\title{
The effect of mobile learning on students' attitudes using mobile devices
}

Shai Solomovich, Ciprian Ceobanu 


\title{
The effect of mobile learning on students' attitudes using mobile devices
}

\author{
Shai Solomovich ${ }^{a}$, Ciprian Ceobanu ${ }^{b^{*}}$ \\ ${ }^{a}$ Kaye Academic College of Education, Azriel Nitzani 6, Beer Sheva, 8414201, Israel \\ b “Alexandru Ioan Cuza University”, Bulevardul Carol I, Nr.11, 700506, Iaşi, România \\ *Corresponding author: ciprian@uaic.ro
}

\section{Abstract}

\section{Keywords:}

Mobile learning; ubiquitous learning; meaningful learning; digital learning; Self-Determination Theory.
Mobile learning (m-learning) has the potential to vastly change and improve education as we know it. Its main advantage is in extending the educational contexts to any place and any time. This leads to possibilities of more active and experiential learning. Furthermore, it greatly improves the potential for communication and access to information. All of these improvements, if utilized properly, can lead to more meaningful learning and more internal motivation for learning. However, these changes are not easy to implement and require the overcoming of several obstacles. This study aimed to investigate the attitudes towards m-learning and its relationships with ubiquitous learning, experiential and active learning, meaningful learning, cooperative learning, internal motivation for learning, and demographic variables. In order to measure these constructs, questionnaires were completed by 200 participants. The results suggest that the youngest generations (15-17 years old) and those who used their mobile phones the most have the highest attitudes towards m-learning. There were no differences amongst genders or people with various levels of education. Furthermore, the effects of mobile and ubiquitous learning on meaningful learning were mediated by collaborative and experiential and active learning. Lastly, the effects of mobile and ubiquitous learning on internal motivation for learning were direct. The findings indicate the importance of utilization of mobile learning and its positive consequences on both academic and personal aspects of the students' lives.

\section{Zusammenfasung}

\section{Schlüsselworte:}

Mobiles Lernen;

allgegenwärtiges Lernen;

Sinnvolles Lernen; digitales

Lernen;

Selbstbestimmungstheorie.
Mobiles Lernen (M-Learning) hat das Potenzial, die Bildung, wie wir sie kennen, stark zu verändern und zu verbessern. Sein Hauptvorteil besteht darin, den Bildungskontext auf jeden Ort und zu jeder Zeit auszudehnen. Dies führt zu Möglichkeiten des aktiven und erfahrungsorientierten Lernens. Darüber hinaus verbessert es die Möglichkeiten der Kommunikation und des Zugangs zu Informationen erheblich. Alle diese Verbesserungen können bei richtiger Anwendung zu einem sinnvolleren Lernen und zu mehr innerer Lernmotivation führen. Diese Änderungen sind jedoch nicht einfach umzusetzen und erfordern die Überwindung mehrerer Hindernisse. Diese Studie zielte darauf ab, die Einstellungen zum M-Learning und seine Beziehungen zu ubiquitärem Lernen, erfahrungsbasiertem und aktivem Lernen, sinnvollem Lernen, kooperativem Lernen, interner Lernmotivation und demografischen Variablen zu untersuchen. Um diese Konstrukte zu messen, wurden Fragebögen von 200 Teilnehmern ausgefüllt. Die Ergebnisse deuten darauf hin, dass die jüngsten Generationen (15-17 Jahre) und diejenigen, die ihre Mobiltelefone am häufigsten benutzen, die höchste Einstellung zum M-Learning haben. Es gab keine Unterschiede zwischen den Geschlechtern oder Personen mit verschiedenen Bildungsabschlüssen. Darüber hinaus wurden die Auswirkungen des mobilen und ubiquitären Lernens auf das sinnvolle Lernen durch kollaboratives und erfahrungsbasiertes und aktives Lernen vermittelt. Schließlich waren die Auswirkungen des mobilen und ubiquitären Lernens auf die interne Lernmotivation direkt. Die Ergebnisse zeigen die Bedeutung der Nutzung des mobilen Lernens und seine positiven Auswirkungen sowohl auf die akademischen als auch auf die persönlichen Aspekte des Lebens der Studierenden.

\section{Introduction}

As a result of the emergence of mobile learning (m-learning), both educators and students can learn in ways that were previously impossible. Since mobile devices are portable and multifunctional, the learner does not need to be connected to traditional, formal learning. Consequently, learning becomes possible in different times and places. The implication of $\mathrm{m}$ learning is the modification of both teachers' and students' duties and the curriculum itself, in order to utilize the potential that it has. Research points towards a positive correlation between the level of effective usage of mobile devices and the perception of their impact. It is becoming more and clearer that education is changing in the 21 st century, and that the professionals working in this domain will need to rethink their methods (Ciampa, 2014; Huang et al., 2010). 
Digital learning is the latest advancement within pedagogical infrastructure in the $21 \mathrm{st}$ century. It includes teaching through utilizing technology and communication in an online learning environment, as well as use of appropriate educational methods (Luna Scott, 2015; Meishar-Tal \& Forkosh-Baruch, 2016). This type of learning is based on the use of traditional teaching materials on one hand, and the use of available online resources on the other. Its goal is building knowledge based on research, sharing, and expansion and deepening. Digital learning involves a range of pedagogical means implemented through technology and communication with the aim to promote learning (Corbeil \& Corbeil, 2013; Ligi \& Raja, 2017). The theoretical infrastructure of digital learning is based on two central pedagogical principles: knowledge building (constructivism) and cooperative learning, both of which emphasize meaningful learning. Mobile technology has thoroughly infiltrated all aspects of our lives, but it has not yet been properly utilized as an educational platform (Deaton et al., 2018). Optimal functioning of education in the 21 st century requires improving teaching and learning processes in order to promote the pupils' meaningful learning, and m-learning may be a potent tool for this (Ciampa, 2014; Kärki et al., 2018).

\section{Theoretical background}

Mobile learning cannot be easily defined. Previously existing conceptual frameworks and definitions have been left behind due to technology developing at a very quick pace. There are many different terms and definitions related to novel technologies and their functions (Guri-Rosenblit, 2013). Numerous keywords related to m-learning may sometimes be confusing and include terms such as hypermedia assisted learning, ubiquitous computing, mobile instruction technologies, handheld learning and e-learning represent a group of terms that has more or less similar meaning (Giemza et al., 2012; Rossing et al., 2012). However, for the purposes of this study, mobile learning is defined as a type of learning which is implemented through content and social interaction, across numerous contexts and personal devices (Crompton, 2017), such as cell phones, personal digital assistants, laptops or iPods (Stevens \& Kitchenham, 2011).

Since mobile devices are convenient and portable, students may use them for leisure and social networking, but also for schoolwork. The variety of opportunities provided by mobile technology supports learning and performance in and out of the classroom, for instance, in laboratories and other learning environments (Martin \& Ertzberger, 2016). In other words, it allows students to access information and communicate at any time and any place (Traxler \& Kukulska-Hulme, 2015). The technological mobility, thus, leads to learners' mobility. And as a consequence, the process of learning becomes completely mobile as well. Students may be taught how to use novel technologies for educational purposes by either educators or their peers (Adedoja et al., 2013).

There is a discussion amongst authors in the literature about how useful m-learning is in accessing higher education (Corbeil \& Valdes-Corbeil, 2007; Krull \& Duart, 2017). The following concerns and open questions about m-learning have been identified:

1. The possibility to purchase technological devices that students from low-income families have in comparison to students from high-income families (within the same age group).

2. How much should m-learning be used in schools?

3. Universities must improve their wireless infrastructure and adjust it to the connectivity requirements as the mobile technologies develop. Educators should not use apps that require a lot of internet bandwidth in their classrooms if they cannot ensure strong Wi-Fi signals (Nortcliffe \& Middleton, 2013).

4. M-learning demands a steady pedagogical support from institutions for both students and faculty members.

National Survey of Students' Engagement (NSSE) found that mobile education technologies increased students' engagement in collaborative learning. The survey indicated that there are three main advantages of learning via mobile technology: (i) the quick access to information, (ii) the ability to synchronize devices, and (iii) the improvement of collaboration. M-learning motivates students to learn and implement course material in interaction with other students, thus, sustaining a social constructivist view of teaching (Bryant, 2013; Johnson, 2012).

According to Sharples (2013), this new form of learning is a collaborative process of discovery through dialogue, which should be held in an authentic environment. The process of discovery, the 
interpretations given during the process, and even the way knowledge and technology work together all change frequently. This approach challenges traditional learning because it undermines the centrality of the basic elements of education - the classroom, the curriculum and the concept of "imparting knowledge", which are the three key factors in teaching, particularly in academic teaching. One of the main challenges in this domain is to retain the focus on both content and technology (Asiimwe et al., 2017). The multitude of technologies provides students with various opportunities to benefit from both real-world sources and digital devices by integrating them into their learning environment. Knowledge cannot stand apart of its context, therefore situated learning requires knowledge to be presented in authentic texts in order to be meaningful. This integration leads to a ubiquitous approach to learning, which means that the students can see the knowledge holistically, rather than only fragmented. This is also an important requirement for meaningful learning. Mobile technologies support the learning environment regardless of the students' place, and they can be used in any context to help the learners focus on the context (Joo et al., 2016). Garrison (2011) explains that learning comes through activities and contexts, but he comments that in schools concepts that are not related to natural context are often taught. M-learning may be a pathway to bridging such situations, in which the context may be difficult to create with traditional means. Thus, m-learning may lead to more and more successful experiential and active learning, as it helps create this connection.

More specifically, mobile technology enabled the creation of a new learning method called "here and now learning", meaning that students can access information anytime and anywhere and adjust it to the context of their learning (Traxler \& Crompton, 2015; Ligi \& Raja, 2017). The "here and now" approach encourages students to create and receive content, note their observations, record sounds, and share their location-based projects with others (Mueller et al., 2012). However, there are two open questions regarding this method: (i) How impactful are the effects of "here and now" m-learning on student achievements in comparison to computer-based instructions (CBI)? (ii) Is student attitude improved by the "here and now" m-learning when compared to CBI? Learning can be influenced by the context in which it takes place, so knowledge should be placed within the context of authentic activities - this is the fundament of the "here and now" framework (Traxler \& Crompton, 2015).

As NSSE identified, collaborative learning is one of the main advantages of the utilization of m-learning. Collaboration includes conversation and data sharing, highlighting the use of networked connections and interactions between learners, teachers, and other people, as well as exchanging ideas and sharing resources through collaborative assignments (Wang et al., 2009). This complex system consists of multimodal, communicative aspects of m-learning, more specifically information searching, production, and sharing (Mills et al., 2014; Sharples, 2013). Collaborative learning produces an efficient bridge for seamless transfers amongst online environments, consisting of private, semi-private, and public networks. These networks enable learners to collaborate with skilled learners and teachers in their local community (e.g., school-based classes) as well as unknown skilled learners and experts in broader communities. Royle et al. (2014, p. 34) expressed the view about this environment by their observation: "Though learning was once bounded by time and place, now, with mobile devices, it can seamlessly retrofit any human interaction to, as Dewey put it, emancipate the mind".

Cobcroft et al. (2006) proposed that mobile technologies can sustain learners' engagement in creative, collaborative, critical, and communicative learning activities. Assisted by m-technology, students can investigate, discuss their issues, collaborate, and create knowledge not only in the classroom. To apply this idea, students can create centered activities, collaborate and advise each other through apps that function as an interactive classroom to promote the students' collaboration and the digital skills of the curriculum (Chou et al. 2012; Luna Scott, 2015).

Due to the many positive aspects, the usage of mobile learning (m-learning) platforms in educational institutions is gradually increasing. The main obstacle to even greater usage is represented by the doubts held by the stakeholders in the education system. Despite this, a study has shown that school principals positively evaluated (88/100) the use of digital learning in high schools and its implementation. The use of mobile devices for teaching provides a novel and unique pedagogical approach. It could lead to an increase in students' motivation, initiative, and creativity, since it provides the learner with freedom of choice and personalization that is related to a wide 
range of possibilities in terms of managing their own learning (Chang et al., 2016; Ciampa, 2014).

Although some studies have demonstrated the advantages of computer and network-based learning (Chu et al., 2010), educators still accentuate the importance of students' activities related to real-world problems. They think that technologies should direct the learner and that students should learn with, instead of from them (Jonassen \& Carr, 2020). The integration of technology enables the students to create more learning activities that fit their individual learning styles. For example, standard activities in college classrooms, such as lectures and discussions, have been partially altered and enhanced by technological devices. Such a situation is described in a study (Beckmann, 2010) by a student who needed a different learning pace in order to focus on specific things - he reported how his iPad kept him actively involved and allowed him to learn with his hands and eyes, instead of sitting and listening. The usage of mobile devices had a positive impact in this study - the student's attitudes and relations were improved due to the learning barriers being removed, which resulted in all students being put on the same level, and enabled to engage in diverse activities (Beckmann, 2010). This is an example of how m-learning positively affected active and experiential learning, and how the students were able to utilize their own strengths to overcome their weaknesses.

Some researchers claim that educators must allow students to exercise utilizing m-learning in class, in order for them to adapt to the devices and reduce their frustration (Martin \& Ertzberger, 2016). To prove that mobile technologies are not difficult to use, a research team (Martin \& Ertzberger, 2016) gave students a few minutes to explore and experience new mobile devices for the first time. Findings from one of the studies point out that the use of a mobile tablet (iPad) in the classroom fits well within the learning environment. On the one hand, students enjoyed the benefits of iPads, such as their design and elements (touch screen and keyboard feature). The usage of iPads resulted in students asking fewer questions and being more focused. The students who used the iPads only a few times during the semester had to put in more effort than those who used them on a regular basis. They had access to an authentic, ubiquitous learning environment containing accurate information and structured content. On the other hand, the negative aspect was the free access to social networks, e-mail, and games that the students had. Thus, those who preferred to use the apps during class and those who found it difficult to listen to the teacher and explore the apps at the same time gave more negative reports.

Usually, when students report positive experiences with technology, they mention the instructional design as a decisive factor that contributes to their comfort and success (Armstrong et al., 2011; De Winter et al., 2010). However, some students report that instructional technology does not contribute to effective performance in classrooms (Armstrong et al., 2011). The literature also suggests that assisting the instructors is necessary, as the success of using new technologies in the classroom generally depends on them (Chang et al., 2016; De Winter et al., 2010).

\subsection{Meaningful learning}

Meaningful learning means that a concept that is being learned is actually and completely understood, so that connections with other knowledge can be constructed and it can be applied in various contexts (Mayer, 2002). M-learning improves the learning process and communication amongst students, as well as between educators and students. Furthermore, continuous changes in technology that m-learning utilizes have set up new possibilities and challenges for meaningful learning (Bestwick \& Campbell, 2010). Jonassen \& Carr (2020) assessed the possible use of technologies (such as Mindtools) that contribute to students' deep thinking, which is important for meaningful learning. It is important to understand the complex process of integrating m-learning into teaching, since the pedagogical uniqueness of this integration is exactly what can lead to meaningful learning (Huang et al., 2011).

\subsection{Mobile learning in higher education}

Mobile technology has become prominent in higher education. Its increasing usage in colleges includes learning activities, along with communication between students and their faculties (Alzaza \& Yaakub, 2011). The benefits of mobile technology usage in academic, social, and economic domains have worldwide implications. UNESCO published extensive publications on the potential of mobile technology applications in education, including policy guidelines in this area and their implementation. These publications present unique advantages of mobile technology (Hanemann, 2014). Some of these advantages include striving for equality in education, promoting personalized learning, providing immediate feedback and assessment to 
advance learning regardless of time or place, using time effectively, building learning communities, supporting contextual learning, promoting integrative learning, bridging formal and informal learning, reducing damage to education in disaster or conflict areas, assisting learners with special needs, improving communication and learning management, and maximizing the benefit-cost ratio.

Furthermore, UNESCO highlights the possibilities inherent to m-learning and the need for further research on it. As mentioned before, mobile technologies have great potential for higher education: they can motivate students to learn and persevere in tasks, personalize learning in terms of content, learning methods and learning pace, make the learner active by enabling him/her to participate in the interaction outside the classroom and make decisions related to his/her learning and enable the learning to occur at any place and at any time while simultaneously building knowledge, creativity and cooperation (Krull \& Duart, 2017).

In order to advance the learning process through the usage of digital technologies and improve trust in them, faculties should invite students who have a deep knowledge of technology to share it with their colleagues and help them. For example, at Indianapolis University, students learned how to use the iPad as a part of a Faculty Learning Community (FLC). They learned how to use iPads as an additional tool in the classroom. M-learning can be applied to higher education institutions because most students already have mobile devices (tablets or smartphones) and many academic institutions already have free access to wireless networks (Meishar-Tal \& ForkoshBaruch, 2016). In a study (Papastergiou, 2009) dealing with students learning concepts through utilizing mobile technology, five topics were identified in students' responses to open questions, and each topic mentions the opportunities and the limitations of mobile technologies usage in the classroom. The topics include the following essential points:

- Access and availability of information

- Sharing and collaboration

- Novelty

- Learning styles and preferences

- Comfort and functionality (Papastergiou, 2009)

\subsection{Self-Determination Theory (SDT)}

The theory of self-determination was originally developed by Deci and Ryan (2002) at the University of Rochester, USA. This theory deals with a person's innate tendencies and psychological needs and emphasizes how much a person's internal sources and personality influence and how important they are for the development of his/her behaviour, self-regulation, curiosity, and creative growth. It also deals with challenges, focusing on the term "self-intention", which refers to a person's willingness to take responsibility for his/her personal goals, accomplishments, and failures. The term also refers to exploring different options and making decisions accordingly. Finally, the theory of self-determination proposes the conditions for the development of an autonomous person and the importance of selfdetermination for the normal and adaptive mental development of an individual. An autonomous person is an enterprising person who is consciously driven by their desires and takes responsibility for their own actions. On the contrary, a non-autonomous person allows external factors to direct their decisions and actions. This leads to negative effects such as depression, anxiety, and narcissism (Deci \& Ryan, 2012). A study conducted on student populations from South Korea, Russia, Turkey, and the United States found a link between students' sense of autonomy and positive outcomes. The study connected the theory of self-determination presented above to the students' use of mobile learning, to examine how mobile learning has influenced the students' autonomy and motivation to explore and learn the topics taught in class. They became more intentional autonomous learners, and their learning process became more meaningful (Sha et al., 2012). Thus, m-learning has great potential for allowing students to determine their own intentions and, consequently, increase their motivation and the meaningfulness of their learning. This novel field, of course, requires further research, which is why it will be in the focus of this research paper.

\subsection{The present study}

Based on the cited literature, several research questions were developed. The main goal of the study was to explore the impact of mobile learning on students' attitudes towards the integration of mobile learning in their lessons. More specifically, it investigated their perception of the effect of mobile learning on ubiquitous learning, cooperative learning, experiential and active learning, meaningful learning, and internal motivation for learning. It was generally expected that mobile learning and ubiquitous learning would affect meaningful learning and internal motivation for learning through increasing 
experiential, active and cooperative learning. Aside from this, it was investigated whether or not these core variables differ between different demographic groups, in order to replicate and compare the results with the findings of Al-Emran et al. (2016).

In order to reach these research goals, several specific research questions have been proposed:

RQ1: Are there significant differences in the core variables between male and female participants?

RQ2: Are there significant differences in the core variables amongst participants from different age groups?

RQ3: Are there significant differences in the core variables amongst participants with different duration of education?

RQ4: Are there significant differences in the core variables amongst participants who spend different amounts of time using their mobile devices?

RQ5: What is the predictive power of mobile learning in predicting other core variables?

RQ6: Do experiential, active and cooperative learning mediate the relationship between mobile learning and ubiquitous learning on one side and meaningful learning on the other?

RQ7: Do experiential, active and cooperative learning mediate the relationship between mobile learning and ubiquitous learning on one side and internal motivation for learning on the other?

\section{Methodology}

\subsection{Design}

This study utilized a correlational design. Participants filled out several surveys, and the average scores were compared across groups in order to determine which of them benefited the most from mobile learning. Furthermore, the various types of benefits were correlated in order to determine the relationships amongst them.

\subsection{Participants}

The sample consisted of 200 participants. Their demographic characteristics are presented in Table 1.
Table 1. Frequencies for the sample's demographic characteristics

\begin{tabular}{|c|c|c|c|}
\hline Gender & & $\mathrm{N}$ & $\%$ \\
\hline & Male & 7 & 3.5 \\
\hline & Female & 53 & 6.5 \\
\hline \multicolumn{4}{|l|}{ Sector } \\
\hline & Jew & 40 & 0.0 \\
\hline & Arab & 6 & 8.0 \\
\hline & Other & 4 & .0 \\
\hline \multicolumn{4}{|c|}{ Age group } \\
\hline & $15-17$ & 1 & 0.5 \\
\hline & $18-25$ & 35 & 7.5 \\
\hline & $26-35$ & 9 & 4.5 \\
\hline & $36-45$ & 5 & 0.5 \\
\hline \multicolumn{4}{|l|}{ Role } \\
\hline & Pupils & 1 & 0.5 \\
\hline & Education students & 35 & 7.5 \\
\hline & Students & 9 & 4.5 \\
\hline & Teachers & 5 & 0.5 \\
\hline \multicolumn{4}{|c|}{ Years of education } \\
\hline & 8 & 2 & .0 \\
\hline & 12 & 68 & 84.0 \\
\hline & BA & 9 & 9.5 \\
\hline & MA & 1 & 0.5 \\
\hline \multicolumn{4}{|c|}{ Academic year } \\
\hline & First-year & 165 & 82.5 \\
\hline & Second-year & 17 & 8.5 \\
\hline & Third-year & 12 & 6.0 \\
\hline & Fourth-year & 6 & 3.0 \\
\hline \multicolumn{4}{|c|}{$\begin{array}{l}\text { Average hours of use of cellular phones } \\
\text { (Hours) }\end{array}$} \\
\hline & $1-2$ & 25 & 12.5 \\
\hline & $3-4$ & 84 & 42.0 \\
\hline & $5-6$ & 56 & 28.0 \\
\hline & $7+$ & 35 & 17.5 \\
\hline \multicolumn{4}{|c|}{ Academic achievements } \\
\hline & Low & 3 & 1.5 \\
\hline & Medium & 96 & 48.0 \\
\hline & High & 101 & 50.5 \\
\hline
\end{tabular}

\subsection{Measures}

In order to measure the variables of interest, the following measurements were used. The complete list of items can be found in the Appendix A.

Internal motivation for learning - This scale consists of 4 questions in the questionnaire which measure internal motivation for learning, including interest and willingness for overcoming challenges (e.g., "I want to learn new things"). Scores are based on a 5-point Likert-type scale ranging from 1 (never) to 5 (very often). The score was computed by averaging the responses to the items. This scale showed excellent reliability $(\alpha=.87)$.

Meaningful learning - This scale consists of 6 questions in the questionnaire which measures how digital methods contribute to meaningful learning, including convenience, understanding and exposure to 
different things (e.g., "Contributes to an easier understanding of the studied material"). Scores are based on a 5-point Likert-type scale ranging from 1 (never) to 5 (very often). The score was computed by averaging the responses on the items. The scale showed excellent reliability $(\alpha=.93)$.

Experiential and active learning - This variable consists of 4 questions in the questionnaire which measures the experiential and active learning using the mobile tools, including challenges and fun (e.g., "Contributes to a better understanding of the material being studied "). Scores are based on a 5-point Likerttype scale ranging from 1 (never) to 5 (very often). The score was computed by averaging the responses on the items. The scale showed excellent reliability $(\alpha=.90)$.

Mobile learning - This variable consists of 5-item scale and measures attributes of using mobile tools for learning (e.g., "Mobile learning contributes to better learning from home"). Scores are generated based on a 5-point Likert-type scale ranging from 1 (never) to 5 (very often). The score was computed by averaging the responses on the items. The scale showed satisfactory reliability $(\alpha=.77)$.

Cooperative learning - This variable consists of 3 questions in the questionnaire and measures the contribution of mobile learning for work done in groups, including encouragement and usefulness (e.g., "Can encourage teamwork"). Scores are based on a 5point Likert-type scale ranging from 1 (never) to 5 (very often). The score was computed by averaging the responses on the items. The scale showed excellent reliability $(\alpha=.91)$.

Ubiquitous learning -This variable consists of 2 questions in the questionnaire and measures the attitude towards distant learning everywhere - outside the classroom, including at home. Scores are based on a 5-point Likert-type scale ranging from 1 (never) to 5 (very often). The score was computed by averaging the responses on the items. The scale showed satisfactory reliability $(\alpha=.82)$.

\subsection{Procedure}

The questionnaire was created using the Google forms platform and was distributed to different social media platforms, mainly WhatsApp groups. A large proportion of the respondents were students who had experienced several lessons that utilized m-learning in various fields of study. Using mobile learning, they repeated the material and memorized it individually or in groups, with applications that can also be useful for educational needs, such as: Kahoot, Quizlet, Padlet, Triventy, Google Forms, Mentimeter, Wordwall, Thinglink, Wizerme, PowToon, Canva, Word-wall and other apps. The students received the questionnaire from one of their classmates in the WhatsApp group of their class and responded to it voluntarily, anonymously, in their free time and not as a part of their lessons.

\section{Data analysis}

\section{The data was analyzed using SPSS software version 25.}

Descriptive statistics for demographic characteristics were determined using frequencies. Differences between demographic characteristics in the core variables were evaluated using independent sample t-tests or one-way ANOVAs with Hochberg correction for post hoc analyses. Pearson correlations were conducted for assessing the associations between the core variables. Linear regression models were performed to predict the most essential predictors of meaningful, cooperative, and experiential learning. Finally, structural equation models were performed using Amos software version 26 for assessing the relationships between the core variables.

\subsection{Results}

The results will be presented in line with the answers to specific research questions. The basic descriptive statistics and correlations amongst all the core variables can be seen in Table 2 .

Table 2. Means and standard deviations of core variables and their intercorrelations.

\begin{tabular}{|c|c|c|c|c|c|c|}
\hline Variables & $\begin{array}{l}M \\
\text { (SD) }\end{array}$ & 1 & 2 & 3 & 4 & 5 \\
\hline $\begin{array}{l}\text { Internal } \\
\text { motivation for } \\
\text { learning }\end{array}$ & $\begin{array}{l}3.93 \\
(0.98)\end{array}$ & & & & & \\
\hline $\begin{array}{l}\text { Meaningful } \\
\text { learning }\end{array}$ & $\begin{array}{l}3.74 \\
(1.06)\end{array}$ & $.63 * *$ & & & & \\
\hline $\begin{array}{l}\text { Experiential } \\
\text { and active } \\
\text { learning }\end{array}$ & $\begin{array}{l}3.83 \\
(1.03)\end{array}$ & $.62^{* *}$ & $.92 * *$ & & & \\
\hline $\begin{array}{l}\text { Mobile } \\
\text { learning }\end{array}$ & $\begin{array}{l}3.70 \\
(0.90)\end{array}$ & $.41^{* *}$ & $.73 * *$ & $.72 * *$ & & \\
\hline $\begin{array}{l}\text { Cooperative } \\
\text { learning }\end{array}$ & $\begin{array}{l}3.78 \\
(1.06)\end{array}$ & $.56 * *$ & $.76 * *$ & $.76^{* *}$ & $.60 * *$ & \\
\hline $\begin{array}{l}\text { Ubiquitous } \\
\text { learning }\end{array}$ & $\begin{array}{l}3.79 \\
(0.99)\end{array}$ & $.48^{* *}$ & $.72 * *$ & $.69 * *$ & $.91^{* *}$ & $.62 * *$ \\
\hline
\end{tabular}

Note: $* *=p<.01$

RQ1: Are there significant differences in the core variables between male and female participants? 
In order to answer this research question, an independent sample t-test was conducted. Results (Table 3) show that women had higher internal motivation to learn in comparison to men. No other differences were found.

Table 3. Differences in the core variables between male and female participants

\begin{tabular}{|c|c|c|c|c|}
\hline Variables & $\begin{array}{l}\text { Male } \\
\text { Mean } \\
\text { (SD) }\end{array}$ & $\begin{array}{l}\text { Female } \\
\text { Mean } \\
\text { (SD) }\end{array}$ & $T(d f=198)$ & $\mathbf{P}$ \\
\hline $\begin{array}{l}\text { Internal motivation } \\
\text { for learning }\end{array}$ & $\begin{array}{l}3.61 \\
(1.08)\end{array}$ & $\begin{array}{l}4.03 \\
(0.93)\end{array}$ & 2.62 & $<.01$ \\
\hline $\begin{array}{l}\text { Meaningful } \\
\text { learning }\end{array}$ & $\begin{array}{l}3.56 \\
(1.00)\end{array}$ & $\begin{array}{l}3.79 \\
(1.07)\end{array}$ & 1.23 & .22 \\
\hline $\begin{array}{l}\text { Experiential and } \\
\text { active learning }\end{array}$ & $\begin{array}{l}3.76 \\
(0.94)\end{array}$ & $\begin{array}{l}3.85 \\
(1.06)\end{array}$ & 0.53 & .60 \\
\hline Mobile learning & $\begin{array}{l}3.76 \\
(0.84)\end{array}$ & $\begin{array}{l}3.77 \\
(0.92)\end{array}$ & 0.10 & .92 \\
\hline $\begin{array}{l}\text { Cooperative } \\
\text { learning }\end{array}$ & $\begin{array}{l}3.62 \\
(1.15)\end{array}$ & $\begin{array}{l}3.83 \\
(1.09)\end{array}$ & 1.15 & .25 \\
\hline Ubiquitous learning & $\begin{array}{l}3.68 \\
(1.04)\end{array}$ & $\begin{array}{l}3.83 \\
(0.98)\end{array}$ & 0.90 & .37 \\
\hline
\end{tabular}

RQ2: Are there significant differences in the core variables amongst participants from different age groups?

In order to answer this research question, a oneway ANOVA test was conducted between the participants amongst the ages 15-17 y/o, 18-25 y/o, and 26-45 y/o. Post hoc analyses were conducted with Hochberg correction.

Table 4. Differences in the core variables amongst the age groups of participants.

\begin{tabular}{|c|c|c|c|c|c|}
\hline Variables & $\begin{array}{l}15-17 \\
\text { Mean } \\
\text { (SD) }\end{array}$ & $\begin{array}{l}18-25 \\
\text { Mean } \\
\text { (SD) }\end{array}$ & $\begin{array}{l}26-45 \\
\text { Mean } \\
\text { (SD) }\end{array}$ & $\begin{array}{l}F(d f= \\
197)\end{array}$ & $\mathbf{P}$ \\
\hline $\begin{array}{l}\text { Internal } \\
\text { motivation } \\
\text { for learning }\end{array}$ & $\begin{array}{l}3.39 \\
(1.20)\end{array}$ & $\begin{array}{l}4.01 \\
(0.92)\end{array}$ & $\begin{array}{l}3.93 \\
(0.96)\end{array}$ & 3.79 & .02 \\
\hline $\begin{array}{l}\text { Meaningful } \\
\text { learning }\end{array}$ & $\begin{array}{l}4.16 \\
(1.00)\end{array}$ & $\begin{array}{l}3.70 \\
(1.09) \\
\end{array}$ & $\begin{array}{l}3.67 \\
(0.95)\end{array}$ & 1.82 & .16 \\
\hline $\begin{array}{l}\text { Experiential } \\
\text { and active } \\
\text { learning }\end{array}$ & $\begin{array}{l}4.17 \\
(0.96)\end{array}$ & $\begin{array}{l}3.78 \\
(1.06)\end{array}$ & $\begin{array}{l}3.83 \\
(0.94)\end{array}$ & 1.30 & .27 \\
\hline $\begin{array}{l}\text { Mobile } \\
\text { learning }\end{array}$ & $\begin{array}{l}4.35 \\
(0.79)\end{array}$ & $\begin{array}{l}3.66 \\
(0.94)\end{array}$ & $\begin{array}{l}3.83 \\
(0.70)\end{array}$ & 5.76 & $<.01$ \\
\hline $\begin{array}{l}\text { Cooperative } \\
\text { learning }\end{array}$ & $\begin{array}{l}3.79 \\
(1.25)\end{array}$ & $\begin{array}{l}3.77 \\
(1.11)\end{array}$ & $\begin{array}{l}3.80 \\
(1.05)\end{array}$ & 0.02 & .98 \\
\hline $\begin{array}{l}\text { Ubiquitous } \\
\text { learning }\end{array}$ & $\begin{array}{l}4.19 \\
(0.94)\end{array}$ & $\begin{array}{l}3.69 \\
(1.03)\end{array}$ & $\begin{array}{l}3.93 \\
(0.82)\end{array}$ & 2.76 & .07 \\
\hline
\end{tabular}

The results (Table 4) show a significant difference in the means of internal motivation for learning. Specifically, participants in the 18-25 age group had greater internal motivation to learn compared to the participants in the 15-17 age group (pAdjust $=.02$ ). Furthermore, there was a significant difference in the means for mobile learning. In this case, the participants in the 18-25 age group of had lower mobile learning in comparison to the participants in the 15-17 age group (pAdjust <.01). Lastly, there was a marginal effect for ubiquitous learning. No other differences were found.

RQ3: Are there significant differences in the core variables amongst participants with different duration of education?

For assessing this research question, one-way ANOVA tests were conducted amongst the participants with 8,12 years of study and an academic degree. No differences were found.

RQ4: Are there significant differences in the core variables amongst participants who spend different amounts of time using their mobile devices?

To answer this research question, one-way ANOVA tests were conducted between the participants who used their mobile phone for 1-2, 3-4, $5-6$, and 7+ hours on average. Post hoc analyses were conducted with the Hochberg correction. Results (Table 5) show a significant difference amongst groups in ubiquitous learning. Specifically, participants who used their mobile phone for 7 or more hours on average had higher degrees of ubiquitous learning assessment in comparison to the participants who used their mobile phone for 1-2 hours on average (pAdjust $=.04)$. Furthermore, a marginal difference was found for mobile learning. No other differences were found.

Table 5. Differences in the core variables amongst the groups of participants with different mobile phone usage times.

\begin{tabular}{|c|c|c|c|c|c|c|}
\hline Variables & $\begin{array}{l}1-2 \\
\text { Mean } \\
\text { (SD) }\end{array}$ & $\begin{array}{l}\text { 3-4 } \\
\text { Mean } \\
\text { (SD) }\end{array}$ & $\begin{array}{l}\text { 5-6 } \\
\text { Mean } \\
\text { (SD) }\end{array}$ & $\begin{array}{l}\text { 7+ } \\
\text { Mean } \\
\text { (SD) }\end{array}$ & $\begin{array}{l}F(\mathrm{df}= \\
196)\end{array}$ & $P$ \\
\hline $\begin{array}{l}\text { Internal } \\
\text { motivation for } \\
\text { learning }\end{array}$ & $\begin{array}{l}3.82 \\
(0.80)\end{array}$ & $\begin{array}{l}3.82 \\
(1.04)\end{array}$ & $\begin{array}{l}3.92 \\
(0.99)\end{array}$ & $\begin{array}{l}4.27 \\
(0.85)\end{array}$ & 1.89 & 13 \\
\hline $\begin{array}{l}\text { Meaningful } \\
\text { learning }\end{array}$ & $\begin{array}{l}3.61 \\
(1.05)\end{array}$ & $\begin{array}{l}3.71 \\
(1.06)\end{array}$ & $\begin{array}{l}3.70 \\
(1.05)\end{array}$ & $\begin{array}{l}4.02 \\
(1.09)\end{array}$ & 1.05 & 37 \\
\hline $\begin{array}{l}\text { Experiential and } \\
\text { active learning }\end{array}$ & $\begin{array}{l}3.63 \\
(0.94)\end{array}$ & $\begin{array}{l}3.86 \\
(1.00)\end{array}$ & $\begin{array}{l}3.68 \\
(1.10)\end{array}$ & $\begin{array}{l}4.13 \\
(0.99)\end{array}$ & 1.71 & .17 \\
\hline Mobile learning & $\begin{array}{l}3.46 \\
(0.99)\end{array}$ & $\begin{array}{l}3.80 \\
(0.84)\end{array}$ & $\begin{array}{l}3.67 \\
(0.81)\end{array}$ & $\begin{array}{l}4.06 \\
(1.04)\end{array}$ & 2.53 & .06 \\
\hline $\begin{array}{l}\text { Cooperative } \\
\text { learning }\end{array}$ & $\begin{array}{l}3.57 \\
(1.16)\end{array}$ & $\begin{array}{l}3.72 \\
(1.08)\end{array}$ & $\begin{array}{l}3.85 \\
(1.05)\end{array}$ & $\begin{array}{l}3.95 \\
(1.21)\end{array}$ & 0.72 & 54 \\
\hline $\begin{array}{l}\text { Ubiquitous } \\
\text { learning }\end{array}$ & $\begin{array}{l}3.46 \\
(1.03)\end{array}$ & $\begin{array}{l}3.76 \\
(0.97)\end{array}$ & $\begin{array}{l}3.77 \\
(0.89)\end{array}$ & $\begin{array}{l}4.17 \\
(1.1)\end{array}$ & 2.75 & .04 \\
\hline
\end{tabular}

RQ5: What is the predictive power of mobile learning when predicting internal motivation for 
learning, meaningful learning and cooperative learning?

To answer these research questions, three regression models were created. For each of them, mobile learning and relevant demographic variables were included as predictors. The demographic variables were included to control for their effects when estimating the effect of mobile learning.

For the first one, mobile learning and demographic variables (age, gender, role), which significantly correlated with internal motivation to learn, were used as predictors in the regression model predicting internal motivation. Since age and role correlated $(\chi 2(6)=263.36, p<.0001)$, one of them needed to be removed from the model, in order to prevent multicollinearity. Therefore, as a more relevant predictor, age was used and role was discarded. The results show that the 3 predictors explain $24.7 \%$ of the variance in internal motivation to learn. Internal motivation to learn was positively predicted by mobile learning $(\beta=.47, p<.01)$ and being in the ages of 18 $25 \mathrm{y} / \mathrm{o}(\beta=.42, \mathrm{p}<.01)$ and $25-45 \mathrm{y} / \mathrm{o}(\beta=.32, \mathrm{p}<$ .01 ) (in comparison to being 15-17 y/o). That is, higher mobile learning and being older than 18 y/o positively predict internal motivation to learn.

For the second one, no demographic variables had correlations with meaningful learning, and therefore, only mobile learning was used in the model as a predictor of meaningful learning. Results showed that mobile learning explains $53.5 \%$ in the variance of meaningful learning. Mobile learning had a positive correlation with meaningful learning $(\beta=.73, p<.01)$, that is, the higher the mobile learning, the higher the meaningful learning.

For the third one, no demographic variables had correlations with cooperative learning, and therefore, only mobile learning was used in the model as a predictor of cooperative learning. Results show that mobile learning explains $35.3 \%$ in the variance of cooperative learning. Mobile learning had a positive correlation with cooperative learning $(\beta=.60, p<.01)$. That is, the higher the mobile learning, the higher the cooperative learning.

RQ6: Do experiential and active learning and cooperative learning mediate the relationship between mobile learning and ubiquitous learning on one side and meaningful learning on the other?

To answer the research question, structural equation modeling (SEM) was performed. Mobile learning and ubiquitous learning were exogenous variables; experiential and active learning and cooperative learning served as mediators and meaningful learning was the outcome tested. The model showed partially acceptable fit, $\chi 2(1)=8.25$, p $<.01, \mathrm{CFI}=0.99, \mathrm{GFI}=0.98, \mathrm{NFI}=0.99, \mathrm{RMSEA}=$ $0.19, \mathrm{SRMR}=0.03$.

As Figure 1 shows, mobile learning had a positive correlation with experiential and active learning $(\beta=$ $.54, \mathrm{p}<.01)$, but not with cooperative learning $(\beta=$ $.16, \mathrm{p}=.25)$ and meaningful learning $(\beta=.05, \mathrm{p}=.45)$. Ubiquitous learning had a positive correlation with cooperative learning $(\beta=.42, \mathrm{p}<.01)$, but no correlation with meaningful learning $(\beta=.09, p=.14)$. Experiential and active learning had a positive correlation with meaningful learning $(\beta=72, p<.01)$ and so did cooperative learning $(\beta=.13, \mathrm{p}<.01)$.

Figure 1. Structural equation model of mediation.

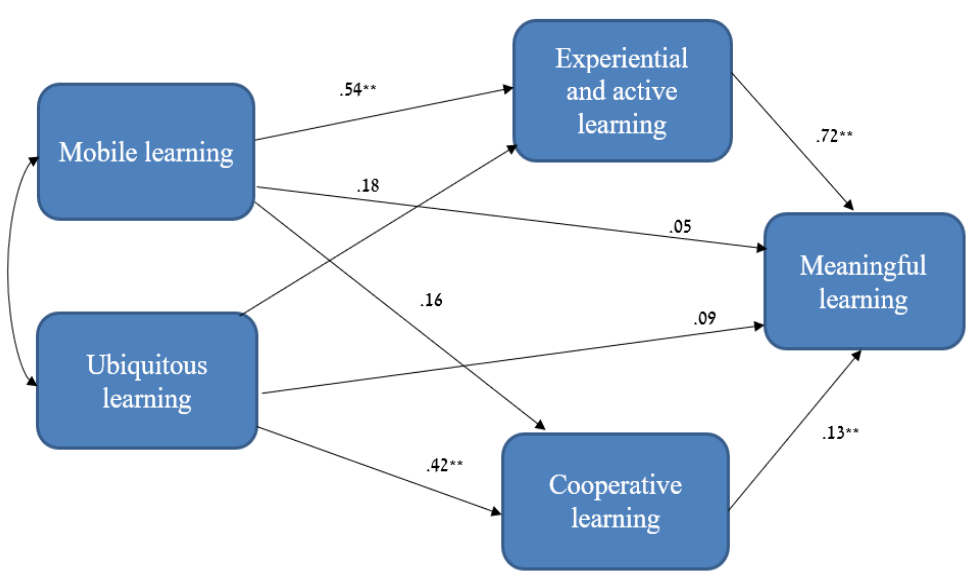

Note. $* *=p<.01$

RQ7: Do experiential and active learning and cooperative learning mediate the relationship between mobile learning and ubiquitous learning on one side and internal motivation for learning on the other?

The SEM model (Figure 2) used to answer this research question included mobile learning and ubiquitous learning as exogenous variables, experiential and active learning, meaningful learning, and cooperative learning as mediators, and internal motivation to learn as the tested outcome tested. The model showed partially acceptable fit, $\chi 2(1)=39.62$, $\mathrm{p}<.01, \mathrm{CFI}=0.97, \mathrm{GFI}=0.95, \mathrm{NFI}=0.97, \mathrm{RMSEA}$ $=0.44, \mathrm{SRMR}=0.06$.

Mobile learning positively correlated with internal motivation to learn $(\beta=.49, p<.01)$, experiential learning $(\beta=.46, p<.01)$, and meaningful learning $(\beta$ $=.41, \mathrm{p}<.01)$, but no correlation with cooperative 
learning $(\beta=.16, p=.25)$. Ubiquitous learning had a positive correlation with internal motivation to learn $(\beta=.41, p<.01)$ and cooperative learning $(\beta=.41, p$ $<.01)$ but no correlations with experiential and active learning $(\beta=.15, \mathrm{p}=.26)$ and meaningful learning $(\beta$ $=.25, \mathrm{p}=.052$ ). Experiential learning had a positive correlation with internal motivation to learn $(\beta=.37$, $\mathrm{p}<.01)$, and so did meaningful learning $(\beta=.30, \mathrm{p}<$ $.01)$. However, cooperative learning did not have a correlation with internal motivation to learn $(\beta=.31$, $\mathrm{p}=.17)$.

Figure 2. Structural equation model of mediation.

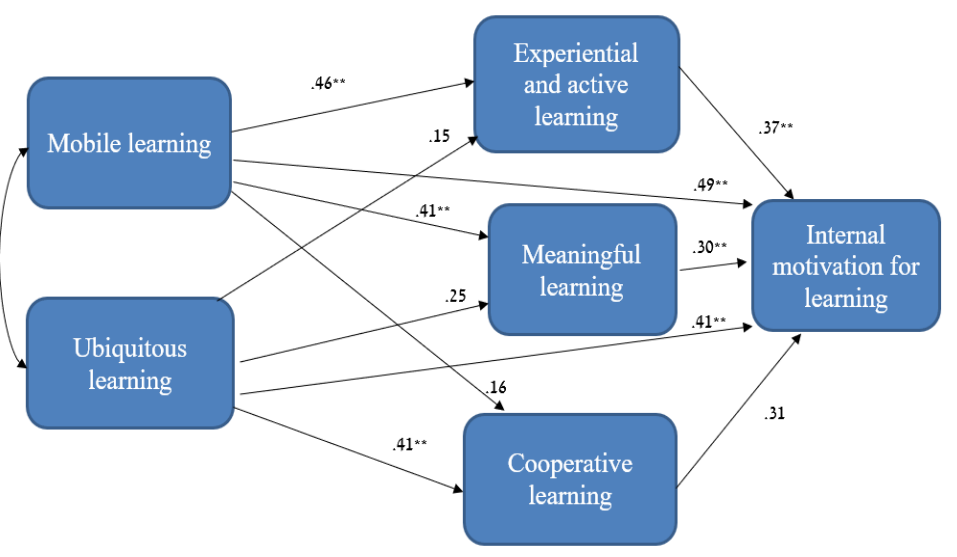

Note. $* *=p<.01$

\section{Discussions}

This study investigated the attitudes towards mlearning and its relationships with ubiquitous learning, experiential and active learning, meaningful learning, cooperative learning, and internal motivation for learning. It also investigated the differences in attitudes towards these phenomena amongst various groups. There were seven specific research questions, which have been proposed to understand the main topic of the study.

The results concerning RQ1 showed that there were no differences in various forms of learning between the two genders. The only difference observed was in the level of internal motivation for learning, which was higher for female participants. This is in line with the findings of Al-Emran et al. (2016), who also found no differences in attitudes towards mobile learning between the two genders. The difference in internal motivation can, thus, be attributed to other factors (such as societal expectations, wish to prove oneself, etc.), and has no connection to mobile learning.
The results related to RQ2 showed that there were differences in the attitudes towards mobile learning based on age. The 15-17 group had higher attitudes towards mobile learning than the older groups, which is partially in line with the results of Al-Emran et al. (2016), who found an omnibus difference amongst all age groups, but no specific differences between any two age groups. This finding indicates that the youngest group has the highest attitudes, which was expected, as they have had access to mobile devices from a very young age and are probably the most accustomed to them. Furthermore, it has been shown that the 18-25 age group had a higher internal motivation than the 15-17 group, which is also sensible, as college education that occurs at the ages of 18-25 is much more self-directed and more important than high school education. In line with selfdetermination theory (Deci \& Ryan, 2012), older students, who have the chance to direct their own learning and live authentic, independent lives, are also more motivated.

The results related to RQ3 showed that there were no differences in any of the core variables amongst the different levels of education. This is in line with AlEmran et al. (2016), who also found no differences. It seems plausible that the level of education simply has no effect on attitudes towards m-learning, as it is more based on other variables, such as level of tech knowledge and usage.

The results related to RQ4 indicated that the participants who used their phones for more than 7 hours had the highest results for attitudes towards mobile learning and for ubiquitous learning. Thus, it is clear that those who use their phones the most also prefer to use them for learning purposes, which is in line with previous studies (Al-Emran et al., 2016; Khaddage and Knezek, 2013).

The results concerning RQ5 are also in line with previous studies, which found that attitudes towards m-learning correlate highly and positively with internal motivation for learning (Sha et al., 2012), meaningful learning (i.e., Ciampa, 2014; Kärki et al., 2018), and cooperative learning (i.e., Bryant, 2013; Johnson, 2012). The more specific relationships amongst these variables were explored in RQ6 and RQ7.

The SEM model of RQ6 was marginally significant, which indicates that further research is needed, but also that some inferences can be made. Mobile learning and ubiquitous learning were positive 
predictors of experiential and active learning, and of cooperative learning, respectively. These two were significant and positive predictors of meaningful learning. This confirms the previously stated expectations that mobile learning is ubiquitous and drives cooperative and experiential/active learning, which then makes learning meaningful. In other words, m-learning does not make learning more meaningful, but by affecting other aspects of learning.

The SEM model of RQ7 was also marginally significant. Furthermore, it showed an absence of a mediation effect. The effects of mobile learning and ubiquitous learning on internal motivation to learn were present both directly and indirectly. Thus, while there may be some mediation present, it is also important to note that mobile and ubiquitous learning directly influence internal motivation for learning as well. This clearly indicates that mobile learning is a very potent tool for increasing the students' motivation. The marginal significance of the SEM models indicates that future studies should try and create different models, which may then be compared with the ones presented in this study. Furthermore, it would be useful if the future studies utilized larger samples, in order to produce more reliable models.

Taken together, these results show the importance of m-learning for the future of education. It is the most preferred way of learning by younger generations and people who use technology the most, which clearly suggests that it should continue being implemented into education more and more. The absence of educational or gender differences in attitudes is also informative and indicates that it is useful for many different populations. Although the youngest participants showed the highest attitudes towards mlearning, this is indicative of the generations that will soon enroll in faculty. Thus, changes in higher education in terms of integrating m-learning will probably be readily accepted by this generation, which will make the transition easier. Furthermore, this will help overcome the potential problems such as not being skilled at using mobile devices, since the students from these generations will already be equipped with these skills.

The most important results of this study are the relationships of m-learning with the other core variables. It positively correlates with all aspects of learning, and it has been demonstrated that these influences may be direct and indirect. When it comes to meaningful learning, the effect of m-learning is indirect, it is mediated by cooperative learning and experiential/active learning. As Sharples (2013) suggested, cooperative learning is in its nature a process of creating meaning through constructing interpretations of the learned material and the world in general. Thus, its promotion through m-learning necessarily leads to more meaningful learning. Furthermore, it has been stressed multiple times in the literature (i.e., Joo et al., 2016; Ligi \& Raja, 2017; Garrison, 2011; Traxler \& Crompton, 2015) that knowledge always needs to be contextualized and that it is necessary to actively work on it in order for it to gain actual meaning. Thus, the "here and now" model of education may be extremely beneficial for the progress of education programs, and it is indisputably made easier through the usage of m-learning.

On the other hand, the impact on internal motivation to learn is direct, which is in line with the self-determination theory (Deci \& Ryan, 2002). The students can utilize mobile technologies to adapt the learning process to their own needs, and thus, they feel more control, autonomy, and authenticity. People have the highest sense of accomplishment and authenticity when they are allowed to explore their needs and fulfil them in the ways that they see fit. This feeling is a necessary condition for normal mental development, quality performance of complex tasks, assistance in dealing with failure, and increasing the student's belief in his/her ability to succeed (Sha et al., 2012). As has been shown in previous studies (Beckmann, 2010), allowing this may be one of the most prominent advantages of the usage of m-learning.

According to the literature, m-learning requires some transformation in the roles of both lecturer and student, and in their academic activities. The literature is based on needs, experiences, and interests of students, who is the center of attention and performs an active role in the learning process. The student can access information any time he/she wants, he/she is responsible for his/her learning, learns at his/her own pace, creates, and shares new information. In the $m$ learning environment, the learner himself makes a large use of personal and active learning. Consequently, the learner learns to evaluate his/her and other peers' learning while collaborating with them (Kukulska-Hulme, 2010). Although these tasks may be demanding and may require a certain level of adaptation from both the students and the faculty members, the benefits that may be gained from it seem to outweigh the costs, especially in the future generations. 


\section{Conclusion}

The present study investigated the relationship of m-learning with demographic variables and core learning variables as experiential/active and collaborative learning. The study was correlational and was conducted on a sample of 200 students, through an online survey. The results suggest that mobile learning is a potent novel technology that can be utilized to improve the educational process, especially for students aged between 15 and 17. These generations will soon enrol into faculty, which makes them ideal in terms of readiness for the transition towards greater use of m-learning. Furthermore, it may be especially useful for the improvement of meaningful learning, through enhancing collaborative learning and experiential and active learning. Lastly, it has a strong, direct effect on the increase of internal motivation for learning, which can be well understood through the lens of the self-determination theory.

This study concludes that in comparison to other age groups, students who belong to the 18-25 age group have a higher internal motivation with the integration of mobile devices in learning. This is meaningful, since higher education in this age group is more self-directed, compared to high school education. In addition, students of all ages who mostly use their smartphones for all kinds of purposes also choose to use them increasingly for learning aims.

This research proves that students acquire increasing motivation when they direct their own learning independently. Mobile learning is considered an effective means for increasing students' internal motivation for learning; this motivation can be aroused directly or through mediating factors. However, the intrinsic motivation of women for learning by mobile devices was higher than that of men; there were no other findings that indicated differences in learning styles between the two genders.

Mobile learning devices enable accessibility and availability, learning management by the student independently, communication and transfer of information anywhere and anytime, accessibility between student and teacher and in addition, it allows easier communication in collaborations between student and peers and between learning groups. It can be identified that the student's attitude to experiential/active and collaborative learning changes positively by using the m-learning devices. This research approves that mobile learning, as a ubiquitous one, leads to these changes in learning. In addition, other mediating and affecting factors turn this learning into a more meaningful one for the students. The higher education system can and will prosper greatly due to the introduction of m-learning, since the students will be more motivated, more collaborative and ultimately, acquire more meaningful knowledge. Thus, the study highlighted m-learning as a learning method of the future that will bring about development to the whole learning process.

\section{Authors note:}

Shai Solomovich is a doctoral student at "Alexandru Ioan Cuza" University from Iași, and a lecturer at Kaye Academic College of Education, Beer Sheva, Israel and a teachers' instructor of ICT. His expertise scans a wide range of sectors in primary, secondary and higher education. His major academic research focuses on ICT for education involving learning development, use of synchronous and asynchronous environments in cloud environments to support education and training. His main academic research deals with integrating smartphones and applications, digital media and ICT. The aim is to award the teachers the ability to combine technological and digital skills in learning activities. A combination of smartphones in lessons is done to increase motivation, experiential and meaningful learning among students. Shay emphasizes the importance of building knowledge, independent learning and a collaborative process of ideas and dialogue between different populations, such as, between Arabs and Jews in a virtual environment in order to improve their mutual relationships.

Ciprian Ceobanu is a University Professor of psychology and educational sciences at "Alexandru Ioan Cuza" University from Iaşi and currently holds the position of Head of the Teacher Training Department within the Faculty of Psychology and Educational Sciences. He manages EduTe Lab activity (Education and Technology Research Laboratory within the same Faculty) and his research interests focus on technology acceptance within educational framework, mobile learning, virtual learning. He has international experience as visiting scholar, coordinator or member of research teams in national and international projects focused on the use of digital technology in teacher training and the use of computers in education. He authored a significant number of books, chapters and articles on above mentioned topics. 


\section{Appendix A}

Items and their descriptive statistics for each of the factors.

\begin{tabular}{|c|c|c|c|c|}
\hline$\alpha$ & $S D$ & $M$ & The questionnaire items included in the factor & The name of the factor \\
\hline \multirow[t]{4}{*}{0.87} & 1.14 & 4.11 & I want to learn new things & $\begin{array}{l}\text { Internal motivation for } \\
\text { learning }\end{array}$ \\
\hline & 1.28 & 3.78 & It's interesting and intriguing to me & \\
\hline & 1.26 & 3.71 & This is a challenging field & \\
\hline & 1.21 & 3.75 & I find great interest in the lessons learned by mobile technology & \\
\hline \multirow{6}{*}{0.93} & 1.16 & 3.81 & Contributes to an easier understanding of the studied material & \multirow{6}{*}{ Meaningful learning } \\
\hline & 1.2 & 3.84 & Helps to understand better the studied material & \\
\hline & 1.09 & 4.01 & Contributes to exposing the student to additional fields & \\
\hline & 1.19 & 3.9 & Is a convenient way to learn & \\
\hline & 1.17 & 3.77 & Allows me to explore topics that interest me & \\
\hline & 1.21 & 3.78 & Contributes to more meaningful learning & \\
\hline \multirow{4}{*}{0.9} & 1.08 & 4.04 & Contributes to a better understanding of the material being studied & \multirow{4}{*}{$\begin{array}{l}\text { Experiential and active } \\
\text { learning }\end{array}$} \\
\hline & 1.18 & 3.9 & Contributes to more active learning & \\
\hline & 1.23 & 3.82 & I want mobile learning to be challenging so I can learn new things & \\
\hline & 1.15 & 3.81 & Gives me fun and pleasure & \\
\hline \multirow{5}{*}{0.77} & 1.22 & 3.92 & Contributes to learning everywhere - inside and outside the classroom & \multirow{5}{*}{ Mobile learning } \\
\hline & 1.29 & 3.73 & Allows me to feel comfortable by learning with a mobile & \\
\hline & 1.11 & 3.76 & Mobile learning contributes to better learning from home & \\
\hline & 1.07 & 3.88 & Mobile learning enables learning while playing & \\
\hline & 1.09 & 3.89 & With mobile learning it is easier to practice the material & \\
\hline \multirow{3}{*}{0.91} & 1.26 & 3.83 & Can encourage teamwork & \multirow{3}{*}{ Cooperative learning } \\
\hline & 1.22 & 3.71 & Allows useful group learning & \\
\hline & 1.22 & 3.84 & Contributes to more collaborative learning & \\
\hline & & & Contributes to learning everywhere - inside and outside the classroom & Ubiquitous learning \\
\hline
\end{tabular}

\section{References}

Adedoja, G., Adelore, O., Egbokhare, F., \& Oluleye, A. (2013). Learners' acceptance of the use of mobile phones to deliver tutorials in a distance learning context: A case study at the University of Ibadan. The African Journal of Information Systems, 5(3):80-93.

Al-Emran, M., Elsherif, H. M., \& Shaalan, K. (2016). Investigating attitudes towards the use of mobile learning in higher education. Computers in Human Behavior, 56, 93-102.

Alzaza, N. S., \& Yaakub, A. R. (2011). Students' awareness and requirements of mobile learning services in the higher education environment. American Journal of Economics and Business Administration, 3(1):95-100. doi:10.3844/ajebasp.2011.95.100

Armstrong, K., Retterer, O., Locke, T., \& Wachira, C.
(2011). mLearning and the Liberal Arts: Exploring Mobile Computing to Support Teaching, Learning and Research. In EdMedia+ Innovate Learning (pp. 303308). Association for the Advancement of Computing in Education (AACE).

Asiimwe, E., Gronlund, Ã. \& Hatakka, M. (2017). Practices and challenges in an emerging m-learning environment. International Journal of Education and Development using ICT, 13(1), Open Campus, The University of the West Indies, West Indies. Retrieved June 19,

from https://www.learntechlib.org/p/180218/.

Beckmann, E. A. (2010). Learners on the move: mobile modalities in development studies. Distance Education, 31(2), 159-173.

Bestwick, A., \& Campbell, J. R. (2010). Mobile learning for all. Exceptional parent, 40(9), 18-20. 
Bryant, V. R. (2013). 21st century youth using critical thinking skills and practicing cyber safety when making digital decisions: An analysis of the digital devices and decisions of youth and parental perspectives of the same (Doctoral dissertation, Fielding Graduate University).

Chang, S. C., Wang, S. Y., \& Hwang, G. J. (2016). A repertory grid-based interactive e-book approach to supporting in-field mobile learning activities in an ecology course. International Journal of Mobile Learning and Organisation, 10(3), 171-186.

Chou, C. C., Block, L., \& Jesness, R. (2012). A case study of mobile learning pilot project in K-12 schools. Journal of Educational Technology Development and Exchange (JETDE), 5(2), 3.

Chu, H. C., Hwang, G. J., \& Tsai, C. C. (2010). A knowledge engineering approach to developing Mindtools for context-aware ubiquitous learning. Computers \& Education, 54(1), 289-297.

Ciampa, K. (2014). Learning in a mobile age: an investigation of student motivation. Journal of Computer Assisted Learning, 30(1), 82-96.

Cobcroft, R. S., Towers, S. J., Smith, J. E., \& Bruns, A. (2006). Mobile learning in review: Opportunities and challenges for learners, teachers, and institutions.

Corbeil, J. R., \& Corbeil, M. E. (2013). What do educational technologists do? The discipline as defined by educational technology practitioners. Issues in Information Systems, 14(2).

Corbeil, J. R., \& Valdes-Corbeil, M. E. (2007). Are you ready for mobile learning?. Educause Quarterly, 30(2), 51.

Crompton, H. (2017). Moving toward a mobile learning landscape: presenting a mlearning integration framework. Interactive Technology and Smart Education.

Deaton, B., Herron, J., \& Deaton, C. C. (2018). Mobile Technology and Learning. In Handbook of Research on Human Development in the Digital Age (pp. 87-108). IGI Global.

Deci, E. L., \& Ryan, R. M. (2012). Self-determination theory. In P. A. M. Van Lange, A. W. Kruglanski, \& E. T. Higgins (Eds.), Handbook of theories of social psychology (p. 416-436). Sage Publications Ltd. https://doi.org/10.4135/9781446249215.n21

De Winter, J., Winterbottom, M., \& Wilson, E. (2010). Developing a user guide to integrating new technologies in science teaching and learning: Teachers' and pupils' perceptions of their affordances. Technology, Pedagogy and Education, 19(2), 261-267.

Garrison, D. R. (2011). E-learning in the 21st century: A framework for research and practice. Routledge.

Giemza, A., Verheyen, P., \& Hoppe, H. U. (2012). Challenges in scaling mobile learning applications: the example of quizzer. In 2012 IEEE Seventh International Conference on Wireless, Mobile and Ubiquitous Technology in Education (pp. 287-291).
Guri-Rosenblit, S. (2013). Challenges facing distance education in the 21st Century: Policy and research implications. Distance and E-Learning in Transition, 122.

Hanemann, U. (2014). Harnessing the Potential of ICTs for Literacy Teaching and Learning: Effective Literacy and Numeracy Programmes Using Radio, TV, Mobile Phones, Tablets, and Computers. UNESCO Institute for Lifelong Learning.

Huang, Y.-M., Po-Sheng, C., Liu, T.-C., \& Tzung-Shi, C. (2011). The design and implementation of a meaningful learning-based evaluation method for ubiquitous learning. Computers \& Education, 57(4), 2291-2302.

Huang, J. J., Yang, S. J., Huang, Y.-M., \& Hsiao, I. Y. (2010). Social learning networks: Build mobile learning networks based on collaborative services. Educational Technology \& Society, 13(3):78-92.

Johnson, L. (2012). Integrating technology into peer leader responsibilities. New Directions for Higher Education, 2012(157), 59-71.

Jonassen, D. H., \& Carr, C. S. (2020). Mindtools: Affording multiple knowledge representations for learning. In Computers as cognitive tools, volume two: No more walls (pp. 165-196). Routledge.

Joo, Y. J., Kim, N., \& Kim, N. H. (2016). Factors predicting online university students' use of a mobile learning management system (m-LMS). Educational Technology Research and Development, 64(4), 611-630.

Kärki, T., Keinänen, H., Tuominen, A., Hoikkala, M., Matikainen, E., \& Maijala, H. (2018). Meaningful learning with mobile devices: pre-service class teachers' experiences of mobile learning in the outdoors. Technology, Pedagogy and Education, 27(2), 251-263.

Khaddage, F., \& Knezek, G. (2013, July). iLearn via mobile technology: A comparison of mobile learning attitudes among university students in two nations. In 2013 IEEE 13 th international conference on advanced learning technologies (pp. 256-258). IEEE.

Krull, G., \& Duart, J. M. (2017). Research trends in mobile learning in higher education: A systematic review of articles (2011-2015). International Review of Research in Open and Distributed Learning, 18(7).

Kukulska-Hulme, A. (2010) Mobile learning as a catalyst for change, Open Learning: The Journal of Open, Distance and e-Learning, 25:3, 181-85, DOI: 10.1080/ 02680513.2010 .511945

Ligi, B., \& Raja, B. W. D. (2017). Mobile learning in higher education. International Journal of ResearchGRANTHAALAYAH, 5(4 (SE)), 1-6.

Luna Scott, C. (2015). The futures of learning 2: What kind of learning for the 21 st century?

Martin, F., \& Ertzberger, J. (2016). Effects of reflection type in the here and now mobile learning environment. British Journal of Educational Technology, 47(5), 932-944. 
Mayer, R. E. (2002). Rote versus meaningful learning. Theory into practice, 41(4), 226-232.

Meishar-Tal, H., \& Forkosh-Baruch, A. (2016). How Do Faculty Members React Towards the Use of Personal Mobile Devices by Students in the Classroom?. In EDEN Conference Proceedings (No. 1, pp. 490-498).

Mills, L. A., Knezek, G., \& Khaddage, F. (2014). Information seeking, information sharing, and going mobile: Three bridges to informal learning. Computers in Human Behavior, 32, 324-334.

Mueller, J. L., Wood, E., De Pasquale, D., \& Cruikshank, R. (2012). Examining mobile technology in higher education: Handheld devices in and out of the classroom. International Journal of Higher Education, 1(2), 43-55

Nortcliffe, A., \& Middleton, A. (2013). The innovative use of personal smart devices by students to support their learning. In Increasing student engagement and retention using mobile.

Papastergiou, M. (2009). Digital game-based learning in high school computer science education: Impact on educational effectiveness and student motivation. Computers \& Education, 52(1), 1-12.

Rossing, J. P., Miller, W., Cecil, A. K., \& Stamper, S. E. (2012). iLearning: The future of higher education? Student perceptions on learning with mobile tablets.
Royle, K., Stager, S., \& Traxler, T. (2014) Teacher development with mobiles: Comparative critical factors. Prospect, 44, 29-42.

Sha, L., Looi, C. K., Chen, W., \& Zhang, B. H. (2012). Understanding mobile learning from the perspective of self-regulated learning. Journal of computer assisted learning, 28(4), 366-378.

Sharples, M. (2013). Mobile learning: research, practice and challenges. Distance Education in China, 3(5), 5-11.

Stevens, D., \& Kitchenham, A. (2011). An analysis of mobile learning in education, business and medicine. In Kitchenham (Ed.), Models for interdisciplinary mobile learning: Delivering information to students (pp. 1-25). IGI Publication.

Traxler, J. M., \& Crompton, H. (2015). Mobile learning. In Encyclopedia of mobile phone behavior (pp. 506-518). IGI Global.

Traxler, J., \& Kukulska-Hulme, A. (2015). Introduction to the next generation of mobile learning. In Mobile Learning (pp. 1-10). Routledge.

Wang, M., Shen, R., Novak, D., \& Pan, X. (2009). The impact of mobile learning on students' learning behaviors and performance: Report from a large blended classroom. British Journal of Educational Technology, 40(4), 673-695. 